УДК 629.735 .03

DOI: $10.18372 / 0370-2197.3(88) .14924$

А. В. БАЛАЛАСВ, К. В. ДОРОШЕНКО

Національний авіаційний університет, Київ

\title{
ЧИСЕЛЬНЕ ДОСЛІДЖЕННЯ ВЛАСНИХ КОЛИВАНЬ ДВОРЯДНОӤ РОБОЧОЇ ЛОПАТКИ СТУПЕНЯ ОСЬОВОГО КОМПРЕСОРА
}

\begin{abstract}
Одним з важливих питань двигунобудування є підвищення ефективності осьових компресорів. Застосування дворядних лопаткових віниів дозволяють покрашити аеродинамічні характеристики компресорів. Проте залишається не до кіния вирімені питання, пов'язані з мічнісними характеристиками дворядних лопаткових вінців, в першу чергу з дослідженням власних коливань і власних форм коливань лопаток. Метою даної роботи є оцінка напірності ступеня осьового компресора 3 однорядним і еквівалентним дворядним робочим колесом, а також порівняння спектру форм власних коливань однорядної і еквівалентної дворядної робочої лопатки. В якості методу дослідження обрано чисельний експеримент. Для моделювання течії в ступенях осьового компресора використовувалася система рівнянь Нав'є-Стокса, яка замикалася моделлю турбулентної в'язкості SST. Для кожного окремого лопаткового віния була побудована розрахункова область, щңо складалася з лопатки і міжлопаткового каналу. Розрахункова область для трьох лопаткових вінців мала близько 13млн. комірок. В якості робочого тіла було обрано повітря при нормальних атмосферних умовах. За результатами моделювання течії в ступенях отримані значення ступеня підвищення тиску. Аналіз отриманих результатів показує, що застосування дворядного РК дає можливість збільшити ступінь підвищення тиску в ступені компресора на 1,6...5,6\% в розглянутих діапазонах відносної частоти обертання $і$ значень коефіиієнту осьової швидкості. Робочі колеса компресорів відносяться до найбільш напружених елементів конструкиії авіаційних газотурбінних двигунів. Досить суттєво загальну вібрачійну напруженість підвищують коливання робочих лопаток і дисків. За допомогою чисельного експерименту отримано спектри власних частот і власних форм коливань однорядної і еквівалентної дворядної лопатки РК. Отримані дані показують, щяо спектр власних частот коливань однорядної і еквівалентної дворядної лопаток суттево відрізняється. Отримані дані необхідно враховувати при проектуванні компресорів з дворядними РК. Існують власні форми коливань дворядної лопатки, де відбувається пересікання лопаток першого і другого ряду.
\end{abstract}

Ключові слова: напірність, коливання, власні коливання, власні форми коливань, робоча лопатка, дворядна лопатка, однорядна лопатка.

Вступ. Одним з важливих питань двигунобудування $є$ підвищення ефективності осьових компресорів. Активні і пасивні методи управління прикордонним шаром дозволяють вирішити цю задачу. Недолік застосування активних методів управління прикордонного шару елементів осьових компресорів є додаткове підведення енергії і складність конструкції. Серед пасивних методів управління прикордонним шаром слід зазначити застосування дворядних лопаткових вінців.

Як показано в роботах [1-6] заміна однорядних лопаткових вінців на дворядні дозволяє збільшити кут повороту потоку $\Delta \beta$. Збільшення кута повороту потоку призводить до збільшення закрутки потоку в міжлопатковому каналі, що, в свою чергу, призводить до збільшення ефективної роботи компресора при незмінній окружній швидкості. Як наслідок ступінь підвищення тиску з дворядним лопатковим робочим колесом (РК) збільшується. Дворядні лопаткові вінці дозволяють підвищити енергію уповільненого потоку в прикордонному шарі, оскі- 
льки частинки повітря прискорюються в щілинному каналі. Перерозподіл потоку повітря сприяє зменшенню кута відставання потоку. Таким чином дослідження спрямоване на вивчення дворядних РК є актуальними.

В роботі [1] автор проводить аналіз заходів, що дозволяють теоретично і практично підвищити якісні і кількісні характеристики осьових компресорів енергетичних установок, зокрема повітряно-реактивних двигунів. Грунтуючись на істотний прогрес в області матеріалознавства і технології виробництва деталей складної форми, в роботі [1] пропонується застосувати в конструкції осьових компресорів відомі і запропоновані за участю автора способи управління обтіканням лопаток. Наводяться результати теоретичного та експериментальних досліджень автора із зазначеної проблеми. В роботі [2] наведено тестову задачу моделювання течії в елементарному дворядному лопатковому вінці, приведено візуалізацію обтікання. В роботі [3] представлені дослідження дворядних лопаткових вінців 3 перекриттям першого і другого рядів лопаток. Показано, що застосування дворядних лопаток в порівнянні з однорядними дає перевагу в розширенні безвідривного обтікання, крім того показано, що аеродинамічний напір такого лопаткового вінця може бути збільшено за рахунок збільшення кута повороту потоку. Автори роботи [4] представили результати щодо оптимізації конструкції дворядного лопаткового вінця. Однією з функцій оптимізації була максимізація кута повороту потоку. В результаті процесу оптимізації рівень втрат в лопатковому вінці знизився при одночасному зростанні ступеня підвищення тиску. Обтікання в дворядних лопаткових вінцях відрізняється від однорядних. В роботі [5] досліджені приторцеві течії в дворядних лопаткових вінцях. Зроблено висновки, що приторцеве обтікання в першому ряді лопаткового вінця аналогічно обтіканню для звичайної однорядної решітки; приторцеве обтікання другого ряду в цілому має загальну спрямованість до спинки лопатки і має характерні області обтікання. Одним із важливих питань, що пов'язано з дослідженням дворядних лопаткових вінців є їх геометричні параметри. В роботі [6] представлені результати дослідження впливу співвідношення хорд лопаток першого і другого рядів дворядних решіток аеродинамічних профілів на значення параметра якості решіток при додатніх і від'ємних кутах атаки. Найбільш істотно ефект дворядності виявляється при кутах атаки $5^{\circ} \ldots 10^{\circ}$ в решітках з розташуванням щілини на відстані $30 . .40$ \% сумарної хорди від носка профілю.

Для дворядних лопаткових вінців робочих коліс досить важливим $є$ питання забезпечення необхідного рівня міцності та надійності. Питання міцнісних характеристик розглянуто автором роботи [7]. Експериментально визначені нестаціонарні аеродинамічні сили і моменти на профілях дворядної компресорної решітки при поступальних та кутових коливаннях профілів кожного ряду. Проаналізована силова взаємодія профілів таких решіток за допомогою аеродинамічних коефіцієнтів впливу. Виконано розрахунки стійкості до флатеру дворядного лопаткового вінця при двох кутах атаки з урахуванням впливу на границю флатера міжрядного співвідношення власних частот лопаток.

Літературний огляд показав, що питання вивчення характеристик дворядних лопаткових вінців на сьогоднішній день є актуальним, проте остається не до кінця вирішені питання пов'язані з міцнісними характеристиками дворядних лопаткових вінців, в першу чергу, з дослідженням власних коливань і власних форм коливань лопаток. 
Постановка завдання. Метою даної статті $є$ оцінка напірності ступеня осьового компресора 3 однорядним і еквівалентним дворядним робочим колесом, а також порівняння форм власних коливань однорядного і еквівалентного дворядного робочого колеса.

Результати досліджень та їх обговорення. Представлене дослідження розділено на два етапи.

Перший етап роботи включав порівняння аеродинамічних характеристик ступеня з однорядним РК і еквівалентним дворядним РК. В даному випадку під еквівалентністю розуміється рівність сумарної хорди і конструктивних кутів входу і виходу потоку. Ступінь компресора складається з трьох лопаткових вінців - вхідного напрямного апарата (ВНА), РК, напрямного апарата (НА). Втулковий радіус на вході становить 0,07 м і периферійний радіус - 0,2 м, висота лопатки РК - 0,13 м. На рис. 1 зображені 3D моделі лопаток однорядного і еквівалентного дворядного РК.
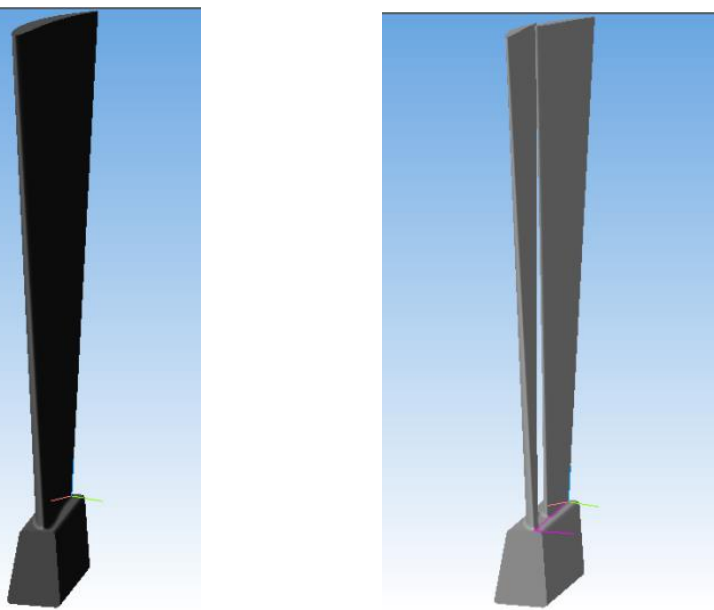

Рис. 1. 3D моделі однорядної і дворядної лопатки РК

В якості методу дослідження обрано чисельний експеримент. Для моделювання течії в ступенях осьового компресора використовувалася система рівнянь Нав'є-Стокса, яка замикалася моделлю турбулентної в'язкості SST. Для кожного окремого лопаткового вінця була побудована розрахункова область, що складалася $з$ лопатки і міжлопаткового каналу. Розрахункова область для трьох лопаткових вінців мала близько 13 млн. комірок. В якості робочого тіла було обрано повітря при нормальних атмосферних умовах.

За результатами моделювання течії в ступенях отримані значення ступеня підвищення тиску. Умови роботи і отримані результати занесено до таблиці 1.

Аналіз отриманих результатів показує, що застосування дворядного РК дає можливість збільшити ступінь підвищення тиску в ступені компресора на $1,6 \ldots 5,6 \%$ в розглянутих діапазонах відносної частоти обертання і значень коефіцієнту осьової швидкості.

Другим етапом дослідження було дослідження власних частот коливань лопаток і власних форм коливань однорядної і дворядної лопатки РК.

Робочі колеса компресорів відносяться до найбільш напружених елементів конструкції авіаційних газотурбінних двигунів. Досить суттєво загальну вібраційну напруженість підвищують коливання робочих лопаток і дисків. Більш ніж $50 \%$ всіх несправностей робочих коліс пов'язано з коливаннями. 
Таблиия 1.

\section{Порівняння напірності ступеня осьового компресора з однорядним і дворядним РК}

\begin{tabular}{|l|c|c|}
\hline \multicolumn{1}{|c|}{$\begin{array}{c}\text { Умови роботи ступеня осьового компре- } \\
\text { сора }\end{array}$} & $\begin{array}{c}\text { Ступінь підви- } \\
\text { щення тиску для } \\
\text { ступеня 3 одно- } \\
\text { рядним РК }\end{array}$ & $\begin{array}{c}\text { Ступінь підви- } \\
\text { щення тиску для } \\
\text { ступеня 3 дво- } \\
\text { рядним РК }\end{array}$ \\
\hline $\begin{array}{l}\text { Відносна частота обертання } \mathrm{n}=0,6 ; \text { коефі- } \\
\text { цієнт осьової швидкості } \lambda=0,4\end{array}$ & 1,13 & 1,15 \\
\hline $\begin{array}{l}\text { Відносна частота обертання } \mathrm{n}=0,6 ; \text { коефі- } \\
\text { цієнт осьової швидкості } \lambda=0,44\end{array}$ & 1,13 & 1,16 \\
\hline $\begin{array}{l}\text { Відносна частота обертання } \mathrm{n}=0,7 ; \text { коефі- } \\
\text { цієнт осьової швидкості } \lambda=0,5\end{array}$ & 1,19 & 1,22 \\
\hline $\begin{array}{l}\text { Відносна частота обертання } \mathrm{n}=0,7 ; \text { коефі- } \\
\text { цієнт осьової швидкості } \lambda=0,54\end{array}$ & 1,18 & 1,3 \\
\hline $\begin{array}{l}\text { Відносна частота обертання } \mathrm{n}=0,8 ; \text { коефі- } \\
\text { цієнт осьової швидкості } \lambda=0,54\end{array}$ & 1,24 & 1,31 \\
\hline $\begin{array}{l}\text { Відносна частота обертання } \mathrm{n}=0,8 ; \text { коефі- } \\
\text { цієнт осьової швидкості } \lambda=0,58\end{array}$ & 1,24 & 1,24 \\
\hline
\end{tabular}

Одне $з$ питань, яке необхідно дослідити для вирішення задачі забезпечення вібраційної надійності - це вивчення власних частот і власних форм коливань лопаток.

В роботі за допомогою чисельного експерименту отримано спектр власних частот коливань однорядної і еквівалентної дворядної лопаток. Дані зведено в таблицю 2.

Табличя 2.

Спектри власних частот коливань однорядної і еквівалентної дворядної лопаток

\begin{tabular}{|c|c|c|}
\hline № & $\begin{array}{c}\text { Частота коливань одно- } \\
\text { рядної лопатки }\end{array}$ & $\begin{array}{c}\text { Частота коливань дворя- } \\
\text { дної лопатки }\end{array}$ \\
\hline 1 & 257,3 & 1240 \\
\hline 2 & 1411,7 & 1413,8 \\
\hline 3 & 1658,3 & 3162,4 \\
\hline 4 & 2076,8 & 3173,9 \\
\hline 5 & 4139,6 & 4027,8 \\
\hline 6 & 4826,8 & 4154,3 \\
\hline 7 & 7882,6 & 5887,12 \\
\hline 8 & 8208,1 & 6078,5 \\
\hline 9 & 8856,7 & 6295,9 \\
\hline 10 & 9818 & 6340,7 \\
\hline 11 & 12211 & 8201 \\
\hline 12 & 12547 & 8412,6 \\
\hline 13 & 14753 & 10226,3 \\
\hline 14 & 16083 & 10452 \\
\hline 15 & 16857,7 & 12701,3 \\
\hline
\end{tabular}


Отримані дані показують, що спектр власних частот коливань однорядної і еквівалентної дворядної лопаток суттєво відрізняється. Цю інформацію необхідно враховувати при проектуванні компресорів з дворядними РК.

Візуалізація спектру власних форм коливань однорядної і дворядної лопатки РК показано на рис. 2, 3.

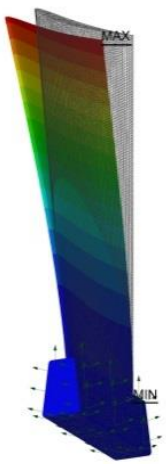

1 форма

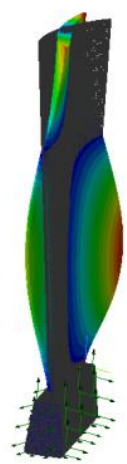

6 форма

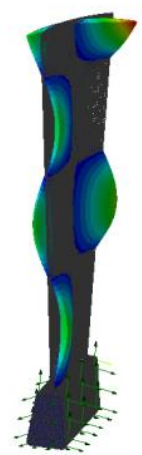

11 форма

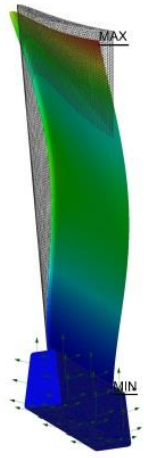

2 форма

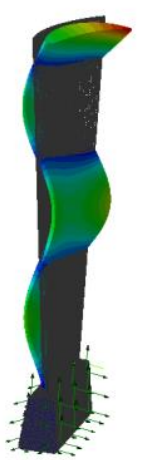

7 форма

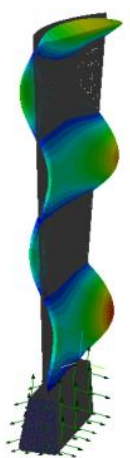

12 форма

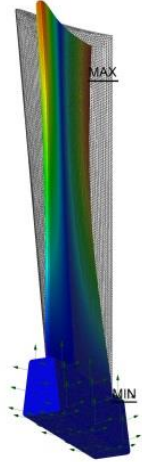

3 форма

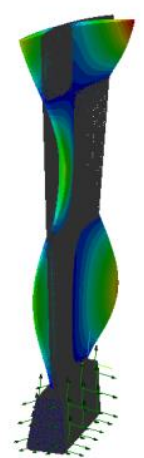

8 форма

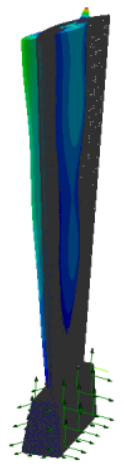

13 форма

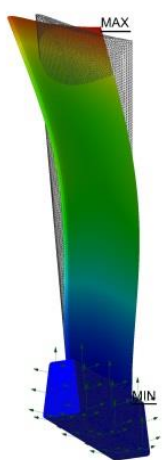

4 форма

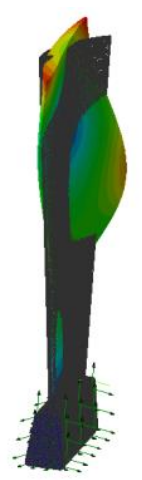

9 форма

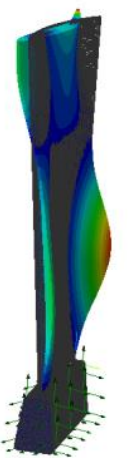

14 форма

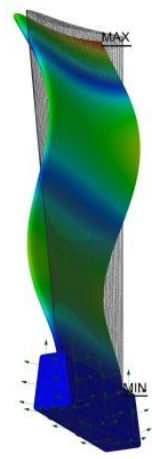

5 форма

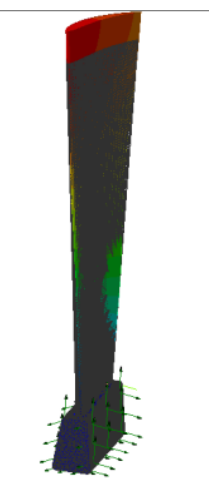

10 форма

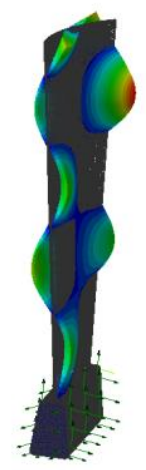

15 форма

Рис. 2. Спектр власних форм коливань однорядної лопатки РК 


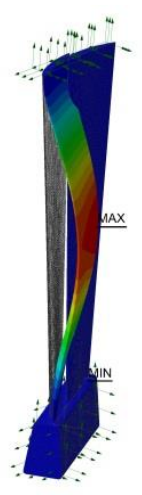

1 форма

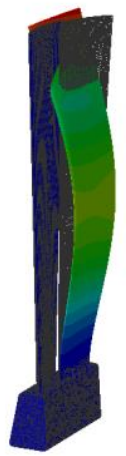

6 форма

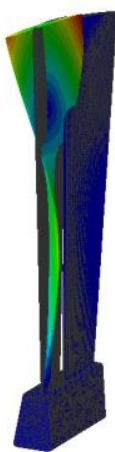

11 форма

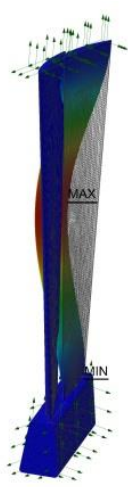

2 форма

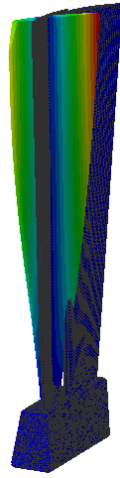

7 форма

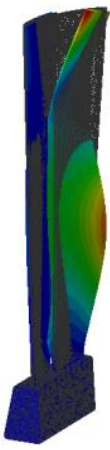

12 форма

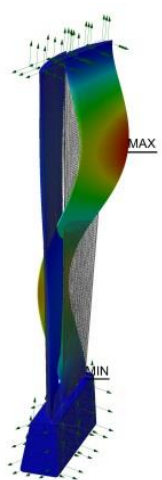

3 форма

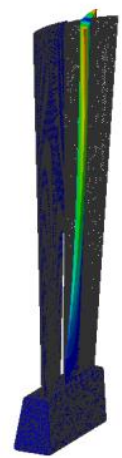

8 форма

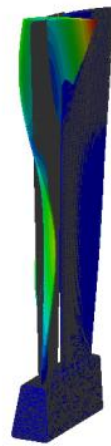

13 форма

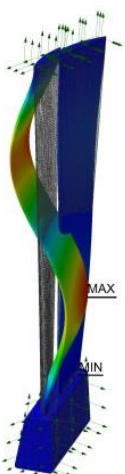

4 форма

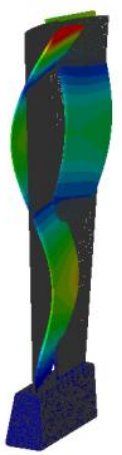

9 форма

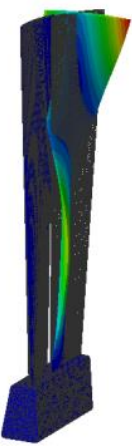

14 форма

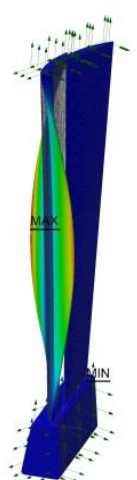

5 форма

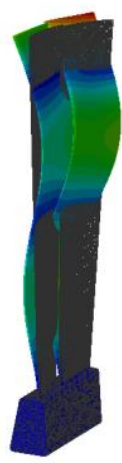

10 форма

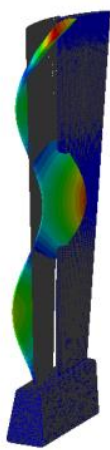

15 форма

Рис. 3. Спектр власних форм коливань дворядної лопатки РК

Аналіз візуалізації спектру власних форм коливань досліджуваних лопаток показує, що власні форми коливань однорядної і дворядної лопатки суттєво відрізняються. Існують власні форми коливань дворядної лопатки, де відбувається пересікання лопаток першого і другого ряду, що призведе до руйнування лопат- 
ки. Отримані дані дають можливість визначати діапазони роботи за вібраційною надійністю, а також розробити заходи щодо уникнення цього явища.

Висновки. В роботі проведено оцінку напірності ступеня осьового компресора 3 однорядним і еквівалентним дворядним робочим колесом. Показано, що застосування дворядного РК дає можливість збільшити ступінь підвищення тиску в ступені компресора на $1,6 \ldots 5,6 \%$ в розглянутих діапазонах відносної частоти обертання і значень коефіцієнту осьової швидкості.

За допомогою чисельного експерименту отримано спектри власних частот i власних форм коливань однорядної і еквівалентної дворядної лопатки РК. Отримані дані показують, що спектр власних частот коливань однорядної і еквівалентної дворядної лопаток суттєво відрізняється. Отримані дані необхідно враховувати при проектуванні компресорів з дворядними РК. Існують власні форми коливань дворядної лопатки, де відбувається пересікання лопаток першого і другого ряду, що призведе до руйнування лопатки. Отримані дані дають можливість визначати діапазони роботи за вібраційною надійністю, а також розробити заходи щодо уникнення цього явища.

\section{Список літератури}

1. Митрофанов А.А. Повышение эффективности осевых компрессоров путем управления обтеканием лопаток/ А.А. Митрофанов // Вестник МАИ. - 2011. - Т.18. №2. - C. 72-82.

2. Balalaiev A. Flow simulation in an elementary tandem vane row of compressor/ A.Balalaiev //Annali d'Italia. - 2020. - №10-1. - P.51-54

3. Schneider T. Flow Characteristics of Axial Compressor Tandem Cascades at Large OffDesign Incidence Angles /T. Schneider, D. Kožulović // ASME Turbo Expo 2013: Turbine Technical Conference and Exposition. - 2013. - V. 6A. - GT2013-94708. - 13 pages.

4. Zhaoyun S. Optimization of Tandem Blade Based on Improved Particle Swarm Algorithm / S. Zhaoyun, B. Liu, M. Xiaochen, L. Xiaofeng // ASME Turbo Expo 2016: Turbomachinery Technical Conference and Exposition. - 2016. - V. 2C. - GT2016-56901. - 12 pages.

5. Балан И.И. Гидродинамические исследования течения в двухрядном лопаточном венце/ И.И. Балан// Вестник ИрГТУ. - 2004. - №1(17). - С. 176-177.

6. Терещенко Ю. М. Исследование влияния соотношения хорд профилей на аэродинамические характеристики двухрядной компрессорной решетки /Ю. М. Терещенко, Е.В. Дорошенко, Дж. Аболлхассан заде // Восточно-Европейский журнал передовых технологий. - 2015. - №5/8 (77). - С. 9-13

7. Цимбалюк В.А. Флаттерная устойчивость двухрядной компрессорной решетки профилей/ В.А. Цимбалюк // Авиационно-космическая техника и технология. - 2007. № 8 (44). - C. 51-55

Стаття надійшла до редакції 30.09.2020.

Балалаєв Антон Валерійович - асистент кафедри механіки Національного авіаційного університету, avbalalaev@ukr.net.

Дорошенко Катерина Вікторівна - д-р. техн. наук, доцент, професор кафедри авіаційних двигунів Національного авіаційного університету, kiki_ua@ukr.net. 


\section{A. V. BALALAIEV, K. V. DOROSHENKO}

\section{NUMERICAL RESEARCH OF NATURAL VIBRATIONS OF TANDEM ROTOR BLADE OF AXIAL COMPRESSOR STAGE}

One of the important issues in engine building is to improve the efficiency of axial compressors. The use of tandem blade rows improves the aerodynamic characteristics of the compressors. However, the issues related to the strength characteristics of tandem blade rows, primarily the study of natural vibrations and natural vibration modes of the blades, remain not fully resolved. The purpose of this work is to evaluate the pressure ratio of an axial compressor stage with a single and equivalent tandem impeller, as well as to compare the modes of natural vibrations of a single and an equivalent tandem rotor blade. A numerical experiment was chosen as the research method. To simulate the flow in the stages of an axial compressor, the system of Navier-Stokes equations was used, which was closed by the SST turbulent viscosity model. For each individual blade row, a computational domain was constructed, consisting of a blade and an interblade channel. The computational area for three blade rows had about 13 million cells. Air was chosen as the working fluid under normal atmospheric conditions. Based on the results of modeling the flow in the stages, the values of the pressure ratio were obtained. The analysis of the results obtained shows that the use of a tandem impeller makes it possible to increase the pressure ratio in the compressor stage by $1.6 \ldots 5.6 \%$ in the considered ranges of the relative rotational speed and values of the axial velocity coefficient. Compressor impellers are among the most stressed structural elements of aircraft gas turbine engines. The overall vibration intensity is significantly increased by the vibrations of the rotor blades and disks. Using a numerical experiment, the spectra of natural frequencies and natural vibration modes of a single and equivalent tandem impeller blade are obtained. The data obtained show that the spectrum of natural vibration frequencies of single and equivalent tandem blades is significantly different. The data obtained must be taken into account when designing compressors with tandem impellers. There are the natural vibration modes of the tandem blade where the blades of the first and second rows intersect.

Key words: pressure ratio, vibrations, natural vibrations, natural vibration modes, rotor blade, tandem blade, single blade. 